Renata Felińska

renata.felinska@lib.uni.lodz.pl

Teresa Górniak

teresa.gorniak@lib.uni.lodz.pl

Biblioteka Uniwersytetu Łódzkiego

\title{
MIEJSCE BIBLIOTEKI UNIWERSYTETU LÓDZKIEGO W ŻYCIU OSÓB STARSZYCH
}

\begin{abstract}
Aging of Polish society has become more and more noticeable in the recent years. That is why state institutions and community organizations take up actions aiming at raising the quality of elderly people's lives. Widely understood activating of senior citizens prevents their loneliness and social isolation, as well as it allows them to stay independent for a longer time.

A scientific library, which collects books, magazines, newspapers, offers access to the internet and electronic sources has great potential to meet the needs of older people in terms of their intellectual development. However, are seniors interested in the research library collections? Not knowing the answer to this question, authors of the article have conducted surveys among the inhabitants of Lodz (163 people). They were asked whether and to what extent older people benefit from the Library of the University of Lodz, what motivates them and what discourages visits to the Library of Lodz. We have also studied reading interests of the elderly, access to the internet and participation in the activities offered by educational institutions. The results of the survey were discussed in the article.
\end{abstract}

Slowa kluczowe: biblioteka naukowa, czytelnictwo seniorów, metody i formy pracy bibliotek, aktywizacja ludzi starszych

\section{Wstęp}

Demografowie alarmują, że społeczeństwo polskie starzeje się, zwiększa się liczba osób starszych, a maleje młodych. Stosunek społeczeństw do ludzi starych zmieniał się $\mathrm{w}$ ciągu wieków. W wielu cywilizacjach starożytnych (Egipt, Indie, Chiny) panowały rządy i rady starców, których autorytet uznawano ze względu na wiek i doświadczenie. Współczesne społeczeństwa nastawione są na szybki rozwój nauki i techniki oraz konkurencję na rynku pracy. Osoby starsze często nie nadążają za takim tempem współczesnego życia, a ich wiedza i doświadczenie przestała być wartością. Czują się nieużyteczni, a nawet niepotrzebni, co z kolei przyspiesza $\mathrm{u}$ nich proces wycofywania się z aktywnego życia i starzenie. Współczesny Europejczyk musi poszerzać wiedzę ustawicznie, aby dostosować się do globalnych zmian w otoczeniu. Pojęcie społeczeństwa uczącego się dotyczy wszystkich grup wiekowych. Motywacja 
do zdobywania wiedzy w każdym wieku jest inna. Osoby starsze mają łatwiejszy wybór, gdyż motywem ich działania nie jest przymus, a wewnętrzna potrzeba samodoskonalenia. Zdobywanie wiedzy i rozwój staje się potrzebą wyższego rzędu. Warto więc zastanowić się nad tym, czym jest starość, czy istnieją obiektywne wyznaczniki progu starości, czy są to jedynie wyznaczniki kulturowe, które pozornie wykluczają osoby starsze ze społeczeństwa wiedzy?

Biblioteka jest jednym $\mathrm{z}$ ogniw koncepcji społeczeństwa wiedzy. Jej główne zadania to: edukacja informacyjna i medialna, propagowanie kultury informacyjnej i budowanie zaufania do informacji. Misją biblioteki uniwersyteckiej powinno być podejmowanie tych działań na rzecz nie tylko środowiska akademickiego, ale całego społeczeństwa.

Biblioteka Uniwersytecka, gromadząc książki, czasopisma i prasę codzienną ma ogromne możliwości zaspokojenia potrzeb seniorów w zakresie rozwoju intelektualnego. Organizuje również interesujące wystawy, spotkania $\mathrm{z}$ autorami, odczyty oraz inne projekty w zakresie kultury. Jednak czy ta oferta jest dla seniorów atrakcyjna, czy rzeczywiście takie są ich oczekiwania i co mogłoby ich zmotywować do odwiedzin Biblioteki? Nie znając odpowiedzi na te pytania, autorki niniejszego artykułu postanowily przeprowadzić badania sondażowe wśród mieszkańców Łodzi.

\section{Osoby starsze w spoleczeństwie wiedzy}

W naukach społecznych starość traktowana jest jako fenomen pierwotny, czyli zjawisko, które podlega badaniom, ale nie można go naukowo zdefiniować ${ }^{1}$. Nie istnieją obiektywne i przyrodnicze wyznaczniki progu starości. Funkcjonujące definicje i periodyzacja życia ludzkiego narzucone zostały przez wymogi kulturowe, ekonomiczne i społeczne ${ }^{2}$. Zofia Szarota dokonała zestawienia periodyzacji wieku starszego według kilku autorów zajmujących się tym zagadnieniem. Przedstawiono je w tab. 1 .

Najbliższy potocznemu spojrzeniu jest podział Aleksandra Kamińskiego, według którego starość rozpoczyna się około sześćdziesiątego roku życia. Około siedemdziesiątki jednostka wchodzi $\mathrm{w}$ fazę wczesnej starości, natomiast w wieku 80 lat w fazę starości sędziwej. Przyjmując, że seniorami są osoby po sześćdziesiątym roku życia, demografowie przewidują, że za trzydzieści lat będą oni stanowili aż $20 \%$ ludzkości ${ }^{3}$. Z prowadzonych badań wynika, że za mniej więcej trzydzieści lat liczba seniorów wzrośnie trzykrotnie, przewyższając liczbę osób przed piętnastym rokiem życia.

Problemem, na który napotykają seniorzy, ale też instytucje wspomagające ich aktywizowanie, jest stereotyp postrzegania osób starszych. Powszechnie

\footnotetext{
${ }^{1}$ Z. Szarota, Gerontologia spoleczna i oświatowa. Zarys problematyki, Kraków 2004, s. 23.

${ }^{2}$ A. Leszczyńska-Rejchert, Człowiek starszy i jego wspomaganie - w stronę pedagogiki starości, Olsztyn 2005, 17.

${ }^{3}$ Z. Szarota, Gerontologia społeczna, op. cit., s. 5.
} 
uważa się, że barierą aktywności życiowej seniorów jest zmniejszona sprawność fizyczna. Przypisuje się im również postawy konserwatywne w sferze politycznej, ekonomicznej i społecznej. Posądza się o zacofanie oraz bierność w zainteresowaniach, ograniczających się między innymi do telewizji i religii. Stereotypy i geranofobię utrwalają środki masowego przekazu. Seniorzy są w nich prezentowani jako osoby ekscentryczne, kłótliwe i niesympatyczne, co sprawia, że w codziennym życiu często dochodzi do dyskryminacji tej grupy wiekowej. Zgodnie z tym stereotypem postrzegają siebie również osoby starsze. Po przekroczeniu przyjętej umownie granicy wieku starzenia, seniorom wydaje się, że nie nadążają za postępem, są niedołężni i nieatrakcyjni. Utwierdzają się w przekonaniu, że na wszytko jest już za późno ${ }^{4}$, ale czy tak jest w rzeczywistości?

Tabela 1

Starość w ujęciu rożnych autorów

\begin{tabular}{|c|c|c|c|c|}
\hline $\begin{array}{l}\text { David } \\
\text { B. Bromley }\end{array}$ & $\begin{array}{c}\text { Andrzej } \\
\text { Bochenek }\end{array}$ & $\begin{array}{c}\text { Aleksander } \\
\text { Kamiński }\end{array}$ & Józef Kocemba & WHO \\
\hline $\begin{array}{l}\text { Do } 65 \text { lat - okres } \\
\text { przed wycofa- } \\
\text { niem się z pracy; }\end{array}$ & $\begin{array}{l}\text { I stopień starze- } \\
\text { nia się }-60-70 \\
\text { lat; }\end{array}$ & $\begin{array}{l}\text { Rozpoczynają- } \\
\text { ca się starość - } \\
\text { ok. } 60 \text { roku } \\
\text { życia; }\end{array}$ & $\begin{array}{l}\text { Starość wczesna } \\
60-70 \text { lat - tzw. } \\
\text { III wiek (young } \\
\text { old) }\end{array}$ & $\begin{array}{l}\text { Początek } \\
\text { starości } \\
\text { - } 60 \text { lat; }\end{array}$ \\
\hline $\begin{array}{l}\text { Powyżej } 65 \text { lat } \\
\text { - emerytura; }\end{array}$ & $\begin{array}{l}\text { II stopień starze- } \\
\text { nia - 70-80 lat; }\end{array}$ & $\begin{array}{l}\text { Wczesna } \\
\text { starość - ok. } 75\end{array}$ & $\begin{array}{l}\text { Starość dojrzała } \\
\text { 75-90 lat - tzw. }\end{array}$ & $\begin{array}{l}\text { Wiek pode- } \\
\text { szły - } 70 \text { lat; }\end{array}$ \\
\hline $\begin{array}{l}\text { Ponad } 70 \text { lat } \\
\text { - wiek starczy; }\end{array}$ & $\begin{array}{l}\text { III stopień sta- } \\
\text { rzenia }-80-90\end{array}$ & roku życia; & old old, & $\begin{array}{l}\text { Wiek starczy } \\
\text { - } 80 \text { lat; }\end{array}$ \\
\hline $\begin{array}{l}\text { Do } 110 \text { lat } \\
\text { - późna starość. }\end{array}$ & lat. & $\begin{array}{l}\text { Starość sędziwa } \\
\text { - powyżej } 80 \\
\text { roku życia. }\end{array}$ & $\begin{array}{l}\text { Długowieczność } \\
90-120 \text { lat - } \\
\text { wiek sędziwy } \\
\text { oldest old long. }\end{array}$ & $\begin{array}{l}\text { Długowiecz- } \\
\text { ność - } 90 \text { lat }\end{array}$ \\
\hline
\end{tabular}

Źródło: Z. Szarota, Gerontologia społeczna i oświatowa. Zarys problematyki, Kraków 2004, s. 27.

Są jednak społeczeństwa, w których przestały funkcjonować powyższe stereotypy, a osoby, które zakończyły działalność zawodową, podejmują inne formy aktywności, czerpiąc z życia satysfakcję. Zestaw uniwersalnych zasad odnoszących się do osób starszych w Ameryce nie wymaga szczególnych środków finansowych, a raczej zmiany postaw wobec siebie samego i świata.

${ }^{4}$ A. Leszczyńska-Rejchert, Stereotypy starości $w$ perspektywie społecznopedagogicznej, [w:] Stereotypy a starość i niepetnosprawność, pod red. A. LeszczyńskiejRejchert, Kraków 2012, s. 20-23. 
Obejmuje między innymi:

- $\quad$ zainteresowanie światem poprzez zachowanie ciekawości świata;

- dążenie do ciągłego rozwoju poprzez zdobywanie wiedzy;

- $\quad$ odczuwanie potrzeby różnorodności i zmian;

- $\quad$ zachowanie przyjaźni i więzów towarzyskich;

- $\quad$ systematyczne ćwiczenia fizyczne, które pozwalają zachować sprawność.

Aktywna osoba starsza powinna podtrzymywać w sobie poczucie ciągłości życia, poprzez nawiązywanie i utrzymywanie kontaktów z osobami młodszymi, nie tylko w obrębie rodziny. Ważne jest również dążenie do zaspokajania własnych potrzeb i unikanie odpoczywania od życia, a więc działanie i ciągła aktywność ${ }^{5}$. Istotne jest odnalezienie i podjęcie działań, które wzbogacą osobowość, uaktywnią fizycznie, dadzą satysfakcję i zadowolenie, a tym samym poprawią jakość życia.

Amerykański gerontolog Harry R. Mood uważa, że edukacja ludzi starszych polega na doskonaleniu ich kompetencji życiowych. Jej celem jest bowiem rozwój osobowości i nadanie sensu istnieniu ${ }^{6}$. Obecnie nikt już nie twierdzi, że starszy człowiek nie może się niczego nauczyć ze względu na mniejsze możliwości poznawcze. Aktywność edukacyjna zapobiega obniżaniu sprawności intelektualnej seniorów i zapewnia im sprawne funkcjonowanie w różnych sferach działania ${ }^{7}$.

Nowe spojrzenie na problemy osób starszych zainicjowało Zgromadzenie Ogólne ONZ, opracowując w 1991 r. Zasady Działania ONZ na Rzecz Osób Starszych. Podkreślano w nich konieczność umożliwienia osobom starszym służby wolontarialnej na rzecz swoich społeczności, ale także stworzenia im warunków do rozwoju, poprzez udostępnienie zasobów edukacyjnych, kulturalnych i rekreacyjnych społeczeństw. Madrycki Międzynarodowy Plan Działań opracowany w 2002 r. podczas II Światowego Zgromadzenia na temat Starzenia się, zachęcał do postrzeganiu seniorów jako „potężnego, niewykorzystanego źródła możliwości”" , a nie jedynie problemu socjalnego.

\section{Instytucjonalne modele aktywizowania osób starszych}

Działania w kierunku właściwego zagospodarowania czasu wolnego osób starszych i zapobieganie stereotypom podjęły w Polsce instytucje kultury, takie jak domy kultury, Uniwersytety Trzeciego Wieku, biblioteki i na przykład parafie. Niestety, Polska przoduje w europejskich statystykach pod względem

\footnotetext{
${ }^{5}$ R.M. Restak, Starsi znaczy mądrzejsi, Warszawa 1999, s. 110-126.

${ }^{6}$ R. Konieczna-Woźniak, Uniwersytety Trzeciego Wieku w Polsce. Profilaktyczne aspekty edukacji seniorów, Poznań 2001, s. 35-36.

${ }^{7}$ A. Fabiś, Edukacja seniorów - odpowiedź na wymagania wspótczesności, [w:] Wyzwania współczesnej edukacji dorostych. T. 2. Unowocześnianie procesu ksztatcenia dorostych, pod. red. A. Fabisia, Mysłowice-Zakopane 2005, s. 153-156.

${ }^{8} \mathrm{R}$. Aleksandrowicz, Czy jesteśmy społeczeństwem otwartym na seniorów. O możliwości dostęu osób starszych do informacji i biblioteki, [w:] Ksiażka, biblioteka, informacja. Między podziałami a wspólnota, pod red. J. Dzieniakowskiej, Kielce 2007, s. 474.
} 
braku aktywności edukacyjnej osób starszych. Według statystyk, tylko około $5 \%$ bierze czynny udział w zajęciach proponowanych przez instytucje kształcenia ustawicznego, typu Uniwersytet Trzeciego Wieku. Podkreślić jednak należy, że zainteresowanie seniorów tą formą aktywności systematycznie rośnie.

Pierwszy polski Uniwersytet Trzeciego Wieku powołano 12 listopada 1975 roku w Warszawie przy Podyplomowym Centrum Kształcenia Kadr Medycznych. Inicjatorką uniwersytetu dla osób starszych była profesor Halina Szwarc ${ }^{9}$. Celem powstałego uniwersytetu było włączenie seniorów w system kształcenia ustawicznego, a także ich aktywizacja fizyczna, psychiczna i społeczna.

W Polsce przyjęto dwa modele funkcjonowania uniwersytetów - francuski i brytyjski ${ }^{10}$. W modelu francuskim Uniwersytet jest zintegrowany $\mathrm{z}$ wyższą uczelnią, która go powołała. Uczestnicy biorą udział w zorganizowanych wykładach, kursach, seminariach, warsztatach oraz zajęciach rekreacyjnoruchowych i turystycznych. Wykładowcami są nauczyciele akademiccy. W modelu brytyjskim nie ma struktur instytucjonalnych i wsparcia uczelni wyższej. Zajęcia organizują sami słuchacze, dlatego najczęściej jest to nauczanie grupowe i eksperymentalne, a wykładowcami są nauczyciele szkół średnich oraz specjaliści z różnych dziedzin, na przykład lekarze, psycholodzy. Najbardziej popularne są zajęcia obejmujące różne zagadnienia i dziedziny wiedzy, naukę języków obcych, obsługę nowych technologii, formy terapii (na przykład muzykoterapia lub arteterapia), turystykę oraz zajęcia rehabilitacyjne i gimnastyczne.

Oprócz Uniwersytetów Trzeciego Wieku coraz więcej zajęć dla seniorów oferują ośrodki kultury. Informacje o ich działalności osoby starsze mogą znaleźć $\mathrm{w}$ prasie oraz w Internecie. Współcześnie funkcjonujące domy kultury to edukacyjno-ekspresyjne ośrodki upowszechniania kultury, budują model edukacyjno-artystyczny lub model artystyczny. Są instytucjami ludycznymi, centrami rozrywki i zabawy, gdzie uczestnicy mogą odreagować problemy codzienności. Różnorodne formy pracy nastawione są na animację i aktywizację całej społeczności. Rozpowszechnionym sposobem aktywnego spędzania czasu wolnego przez osoby starsze jest uczestnictwo w zajęciach Klubów Seniora. Kluby pełnią funkcję kompensacyjną, zapewniając kontakty społeczne; funkcję psychoterapeutyczną, minimalizując stres związany z procesem starzenia; funkcję integracyjną i adaptacyjną, zapewniając przystosowanie się do nowego trybu życia ${ }^{11}$.

\footnotetext{
${ }^{9}$ H. Hrapkiewicz, Uczestnictwo w Uniwersytecie Trzeciego Wieku jako sens życia człowieka, [w:] Problematyka osób w wieku starszym, pod red. J. Rzepki, Mysłowice-Zakopane 2006, s. 53.

${ }^{10}$ B. Ziębińska, Uniwersytety Trzeciego Wieku jako instytucje przeciwdziałajace marginalizacji osób starszych, Katowice 2010, s. 164-168.

${ }^{11}$ A. Leszczyńska-Rejchert, Człowiek starszy i jego wspomaganie - $w$ stronę pedagogiki starości, Olsztyn 2005, s. 170.
} 
Również biblioteki publiczne odgrywają coraz większą rolę w aktywizacji osób starszych w środowisku lokalnym. Organizują wystawy prac, spotkania z utalentowanymi seniorami, konkursy twórczości literackiej, utrwalają i propagują twórczość poprzez wydawanie lokalnych periodyków lub prowadzą terapię zajęciową. Oferta biblioteczna wykracza poza standardowe wypożyczanie książek, chociaż jest to nadal priorytetowy zakres działalności, służący zaspokajaniu potrzeb i oczekiwań osób starszych.

Istotnym elementem działalności bibliotek jest tworzenie płaszczyzny zapewniającej porozumienie międzypokoleniowe poprzez współpracę i wymianę doświadczeń. Biblioteka może stanowić przyjazne środowisko edukacji osób starszych w zakresie najnowszych technologii i korzystania $\mathrm{z}$ nowych źródeł informacji. Przykładem współdziałania międzypokoleniowego w tym zakresie jest Amerykański projekt Senior Access Libraries, w którym osoby starsze są szkolone w zakresie obsługi nowych mediów poprzez wcielanie się w role wykładowców i konsultantów w równolegle prowadzonym programie Youth Access dla osób młodych ${ }^{12}$.

Badania Skat Nielsen, przeprowadzone wśród starszych użytkowników biblioteki w Dani, wykazały znacznie szersze zainteresowania czytelnicze, niekiedy przekraczające oczekiwania innych grup wiekowych. Seniorzy interesują się na przykład nowościami z zakresu nauk przyrodniczych, filozofii i historii starożytnej. Poszukują literatury nie tylko w rodzimym języku, ale także w języku angielskim, francuskim, czy niemieckim ${ }^{13}$.

Korzystanie z polskich bibliotek jest w dalszym ciągu bezpłatne, dostęp do nich nie jest ograniczony barierą materialną. Jednak wiele bibliotek publicznych ze względów finansowych nie może w pełni sprostać wymaganiom IFLA (International Federation of Library Association - Międzynarodowa Federacja Stowarzyszeń i Instytucji Bibliotekarskich), zgodnie z którymi w bibliotekach powinny znaleźć się alternatywne materiały biblioteczne w postaci książek i czasopism mówionych oraz drukowanych dużą czcionką, przeznaczone dla osób starszych.

Zastanówmy się zatem, czy biblioteki uniwersyteckie w większym zakresie niż biblioteki publiczne, a także ośrodki kultury mogłyby sprostać oczekiwaniom współczesnych seniorów, aby umożliwić im funkcjonowanie w społeczeństwie wiedzy?

\section{Biblioteki uniwersyteckie wobec potrzeb osób starszych}

Zbiory bibliotek uniwersyteckich mają charakter uniwersalny i zróżnicowany, dlatego mogą zaspokoić potrzeby różnorodnych, nawet najbardziej wymagających grup odbiorców. Atutem bibliotek jest profesjonalna kadra o wysokich kwalifikacjach, która swoją wiedzą może służyć całej lokalnej

${ }^{12}$ R. Aleksandrowicz, Czy jesteśmy społeczeństwem..., s. 481.

${ }^{13}$ R. Aleksandrowicz, Biblioteka w życiu ludzi starszych, [w:] red. M. Komza, Oblicza kultury ksiązki. Prace i studia z bibliologii, pod red. M. Komzy, Wrocław 2005, s. 151-168. 
społeczności, nie tylko środowisku akademickiemu. Biblioteki uczelniane wyposażone są $\mathrm{w}$ zintegrowane systemy biblioteczne, dysponują większym dofinansowaniem, dzięki czemu ich poziom zaawansowania technologicznego jest dużo wyższy niż bibliotek publicznych.

Zalety te posiada również Biblioteka Uniwersytetu Łódzkiego (Biblioteka, BUŁ), która istnieje od 1945 r. Księgozbiór Biblioteki liczy niemal 3,2 mln woluminów, w jego skład wchodzą podstawowe dzieła ze wszystkich gałęzi wiedzy, zarówno archiwalne, jak i współczesne, polskie i obce. Od 1946 r. Biblioteka otrzymuje egzemplarz obowiązkowy, który do dnia dzisiejszego stanowi główne źródło wpływu. W polityce gromadzenia szczególny nacisk kładzie się na piśmiennictwo z zakresu dziedzin reprezentowanych na Uniwersytecie, to jest nauk humanistycznych, społecznych, matematyczno-przyrodniczych, prawnych, ekonomicznych i innych. Biblioteka gromadzi również w wyborze piśmiennictwo techniczne i medyczne. W 2015 r. Uniwersytet Łódzki i BUŁ obchodzą 70. rocznicę powołania do życia. W związku z jubileuszem stworzono byłym studentom UŁ możliwość uzyskania Karty Absolwenta, z którą dla chętnych do korzystania z usług Biblioteki wiążą się następujące przywileje:

- możliwość wypożyczenia 3 książek na 1 miesiąc bez kaucji (z możliwością samodzielnego przedłużenia na okres 1 miesiąca);

- $\quad$ bezpłatny dostęp do Internetu na terenie BUŁ z możliwością na przykład korzystania ze źródeł elektronicznych subskrybowanych przez UŁ na terenie BUŁ.

Ze względu na pewne ograniczenia, związane $\mathrm{z}$ wiekiem (niedowidzenie, kłopoty z poruszaniem się) osoby starsze mogą wymagać szczególnego traktowania oraz zbiorów bibliotecznych dostosowanych do ich możliwości. Biblioteka dysponuje specjalistycznym sprzętem, który ułatwia osobom niepełnosprawnym, słabowidzącym lub niewidomym korzystanie $\mathrm{z}$ komputera i zbiorów. Są to:

- $\quad$ drukarka brajlowska ViewPlus Pro Gen II: drukuje tekst oraz grafikę wypukłą, a na wydruku brajlowskim czarnodrukowy nadruk;

- $\quad$ klawiatura Intellikeys: dotykowa klawiatura komputerowa;

- $\quad$ klawiatura Big Keys LX: czterokrotnie powiększone klawisze i plastikowa nakładka zapobiega naciśnięciu kilku klawiszy jednocześnie;

- klawiatura Maltron jednoręczna;

- mysz komputerowa Smart Nav AT: mysz sterowana za pomocą ruchów głowy;

- $\quad$ Track Ball: odwrócona i powiększona mysz komputerowa;

- $\quad$ stanowisko komputerowe WINDOW-EYES PL 6.1: z oprogramowaniem udźwiękawiającym;

- urządzenie lektorskie POET Compact: umożliwia odczytywanie przez automatycznego lektora dowolnego tekstu w formie drukowanej;

- powiększalnik MyReader: umożliwia osobom niedowidzącym czytanie na monitorze ekranowym. 


\section{Osoby starsze w BUL w świetle badań wlasnych}

Biblioteka UŁ gromadzi książki, czasopisma i prasę codzienną, a także oferuje dostęp do Internetu i źródeł elektronicznych oraz organizuje wiele wydarzeń kulturalno-edukacyjnych. Posiada ogromne możliwości zaspokojenia potrzeb osób starszych w zakresie rozwoju intelektualnego. Jednak, czy rzeczywiście takie są oczekiwania seniorów? Nie znając odpowiedzi na to pytanie, autorki artykułu przeprowadziły badania sondażowe wśród mieszkańców Łodzi.

W badaniach uczestniczyły 163 osoby powyżej 55 roku życia. Dobór próby badawczej był celowy. Ankiety wypełniali czytelnicy BUŁ, byli pracownicy BUŁ, osoby starsze współpracujące z Uniwersytetem Trzeciego Wieku oraz Klubami Seniora. Niechętnie wypełniali ankietę seniorzy nie będący czytelnikami Biblioteki. Wielu z nich nie wiedziało, że ma możliwość za niewielką opłatą wykupić kartę biblioteczną i korzystać z dostępnych zbiorów. Prowadzenie szeroko zakrojonych badań ankietowych, również w kręgach nie związanych z Uniwersytetem Łódzkiem, było akcją promującą usługi biblioteczne BUŁ i próbą pozyskania nowych czytelników.

Respondentów pytano, czy i w jakim zakresie korzystają ze zbiorów Biblioteki, co ich motywuje, a co zniechęca do odwiedzin. Badano też zainteresowania czytelnicze osób starszych, dostęp do Internetu i udział w zajęciach proponowanych przez instytucje kształcenia. Analiza danych, zawartych w tab. 2 i 3, a także na rys. 1 i 2 , pozwoliła na scharakteryzowanie uczestników badania.

Ankiety wypełniły w większości kobiety (143 osoby). Najliczniejsza była grupa kobiet w wieku 60-70 lat (98 osób). Drugą, co do wielkości, grupę wiekową tworzyły osoby powyżej 70 roku życia (31 osób, w tym kobiety w liczbie 25). Wśród ankietowanych seniorów najliczniej reprezentowani byli mieszkańcy dzielnicy Łódź Polesie (39 osób).

Tabela 2

Charakterystyka respondentów ze względu na wiek, płeć i dzielnicę zamieszkania

\begin{tabular}{|c|c|c|c|c|c|c|c|c|}
\hline \multirow[t]{2}{*}{ Wiek } & \multicolumn{2}{|c|}{ Pleć } & \multicolumn{5}{|c|}{ Dzielnica zamieszkania } & \multirow[t]{2}{*}{ Razem } \\
\hline & $\bar{K}$ & $\mathbf{M}$ & $\begin{array}{c}\text { Lódź } \\
\text { Bałuty } \\
\end{array}$ & $\begin{array}{c}\text { Lódź } \\
\text { Górna }\end{array}$ & $\begin{array}{c}\text { Lódź } \\
\text { Polesie }\end{array}$ & $\begin{array}{c}\text { Lódź } \\
\text { Śródmieście }\end{array}$ & $\begin{array}{c}\text { Lódź } \\
\text { Widzew }\end{array}$ & \\
\hline $\begin{array}{c}\text { Poniżej } \\
60 \text { lat } \\
\end{array}$ & $\begin{array}{l}12 \% \\
20 \\
\end{array}$ & $\begin{array}{l}3 \% \\
5 \\
\end{array}$ & $\begin{array}{l}5 \% \\
8\end{array}$ & $\begin{array}{l}4 \% \\
7\end{array}$ & $\begin{array}{l}2 \% \\
4\end{array}$ & $\begin{array}{l}2 \% \\
4\end{array}$ & $\begin{array}{l}1 \% \\
2\end{array}$ & $\begin{array}{l}15 \% \\
25\end{array}$ \\
\hline 60-70 lat & $\begin{array}{l}60 \% \\
98\end{array}$ & $\begin{array}{l}6 \% \\
9\end{array}$ & $\begin{array}{l}12 \% \\
19\end{array}$ & $\begin{array}{l}12 \% \\
19\end{array}$ & $\begin{array}{l}15 \% \\
24\end{array}$ & $\begin{array}{l}15 \% \\
25\end{array}$ & $\begin{array}{l}12 \% \\
20\end{array}$ & $\begin{array}{l}66 \% \\
107\end{array}$ \\
\hline $\begin{array}{c}\text { Powyżej } \\
70 \text { lat }\end{array}$ & $\begin{array}{l}15 \% \\
25 \\
\end{array}$ & $\begin{array}{l}4 \% \\
6 \\
\end{array}$ & $\begin{array}{l}5 \% \\
8 \\
\end{array}$ & $\begin{array}{l}2 \% \\
4 \\
\end{array}$ & $\begin{array}{l}7 \% \\
11\end{array}$ & $\begin{array}{l}4 \% \\
6 \\
\end{array}$ & $\begin{array}{l}\% \\
2 \\
\end{array}$ & $\begin{array}{l}19 \% \\
31 \\
\end{array}$ \\
\hline Razem & $\begin{array}{l}87 \% \\
143\end{array}$ & $\begin{array}{l}13 \% \\
20 \\
\end{array}$ & $\begin{array}{l}21 \% \\
35 \\
\end{array}$ & $\begin{array}{l}18 \% \\
30\end{array}$ & $\begin{array}{l}24 \% \\
39 \\
\end{array}$ & $\begin{array}{l}21 \% \\
35\end{array}$ & $\begin{array}{l}15 \% \\
24\end{array}$ & $\begin{array}{l}100 \% \\
163\end{array}$ \\
\hline
\end{tabular}

Źródło: opracowanie własne na podstawie wyników ankiety. 
Analiza danych dotyczących uczestników badania ze względu na wykształcenie, posiadanie karty BUŁ i korzystanie z Internetu wykazuje, że większość respondentów zadeklarowała wykształcenie wyższe (108 badanych, z ogromną przewagą humanistów -81 respondentów).

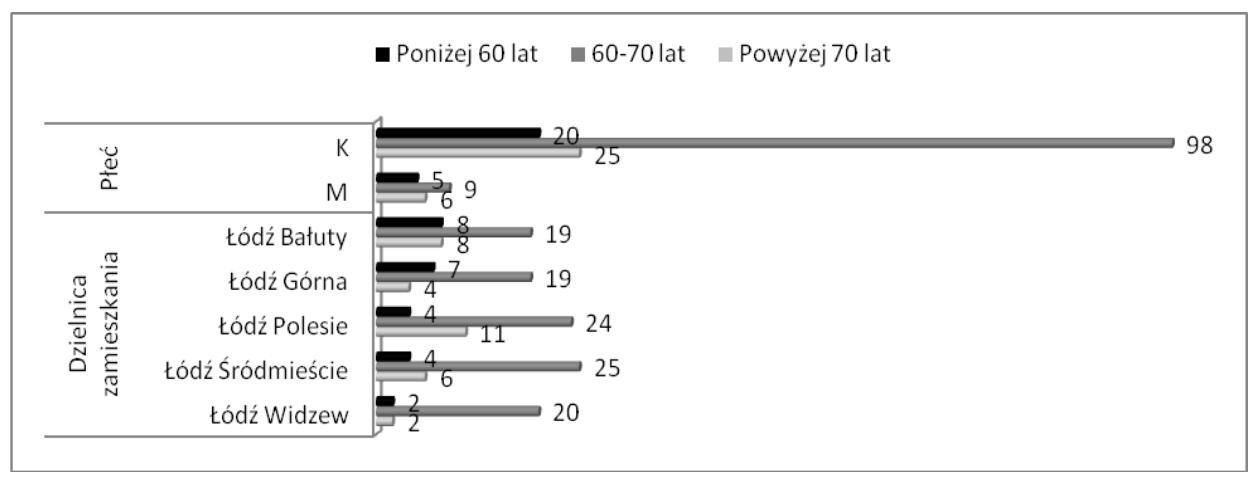

Rys. 1. Charakterystyka respondentów ze względu na wiek, płeć i dzielnicę zamieszkania

Źródło: opracowanie własne na podstawie wyników ankiety.

Wśród 163 osób uczestniczących w badaniach tylko 39 posiadało kartę BUŁ, co stanowiło 24\% ogółu respondentów. Aż 60 (z 81 badanych) osób z wyższym wykształceniem humanistycznym i 13 (z 16 ankietowanych) ze średnim humanistycznym wykształceniem nie korzystało z usług Biblioteki.

Tabela 3

Charakterystyka uczestników badania ze względu na wykształcenie, posiadanie karty BUŁ, korzystanie z Internetu

\begin{tabular}{|l|l|l|l|l|l|}
\hline \multicolumn{1}{|c|}{ Wyksztalcenie } & \multicolumn{2}{c|}{ Czytelnicy BUL } & \multicolumn{2}{c|}{ Korzystanie z Internetu } & \multirow{2}{*}{ Razem } \\
\hline & tak & nie & tak & nie & \\
\hline Podstawowe / zawodowe & $1 \%$ & $5 \%$ & $4 \%$ & $2 \%$ & $6 \%$ \\
& 1 & 8 & 7 & 2 & 9 \\
\hline Średnie humanistyczne & $2 \%$ & $16 \%$ & $5 \%$ & $13 \%$ & $18 \%$ \\
/ ogólne & 4 & 26 & 8 & 22 & 30 \\
\hline Średnie techniczne & $2 \%$ & $8 \%$ & $8 \%$ & $2 \%$ & $10 \%$ \\
/ nauki ścisłe & 3 & 13 & 13 & 3 & 16 \\
\hline Wyższe humanistyczne & $13 \%$ & $37 \%$ & $36 \%$ & $14 \%$ & $50 \%$ \\
/ ogólne & 21 & 60 & 59 & 22 & 81 \\
\hline Wyższe techniczne & $6 \%$ & $10 \%$ & $10 \%$ & $6 \%$ & $16 \%$ \\
/ nauki ścisłe & 10 & 17 & 18 & 9 & 27 \\
\hline Razem & $24 \%$ & $76 \%$ & $64 \%$ & $36 \%$ & $100 \%$ \\
& 39 & 124 & 105 & 58 & 163 \\
\hline
\end{tabular}

Źródło: opracowanie własne na podstawie wyników ankiety. 


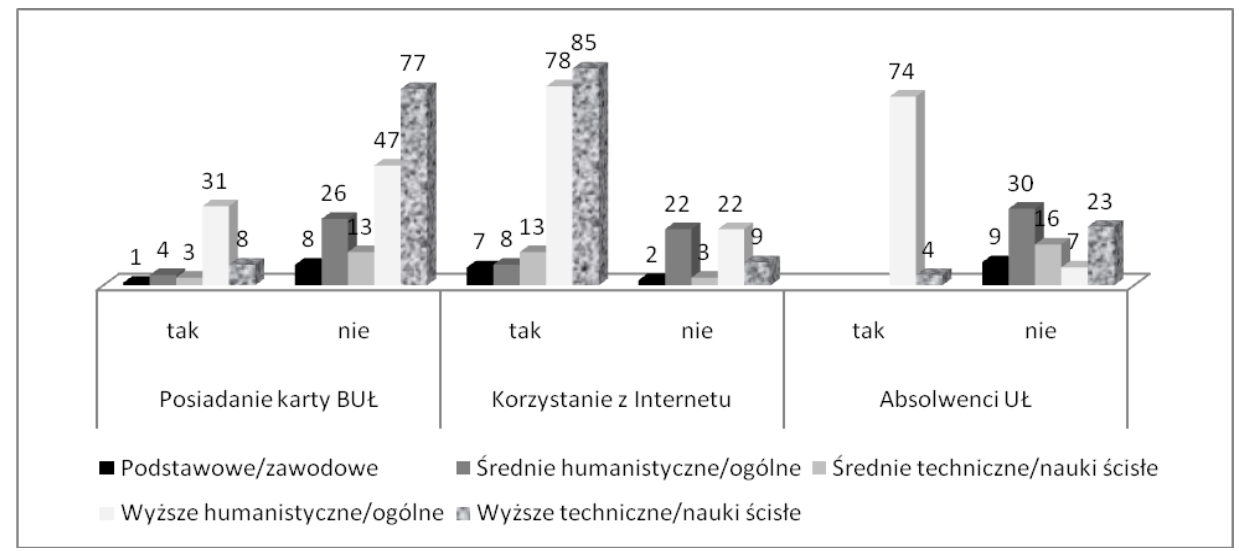

Rys. 2. Charakterystyka uczestników badania ze względu na wykształcenie, posiadanie karty BUŁ, korzystanie z Internetu

Źródło: opracowanie własne na podstawie wyników ankiety.

Wśród respondentów, będących czytelnikami Biblioteki UŁ, dominowali seniorzy z wykształceniem wyższym humanistycznym/ogólnym - 21 osób. Drugą, co do wielkości, grupą czytelniczą były osoby z wykształceniem wyższym technicznym (nauki ścisłe) - 10 osób. Uczestnicy badania w większości korzystali z usług internetowych (105 ankietowanych).

Tabela 4

Posiadanie karty bibliotecznej i zainteresowanie wydarzeniami w BUŁ uczestników badania a ich współpraca z instytucjami działającymi na rzecz seniorów

\begin{tabular}{|c|c|c|c|c|c|c|c|c|}
\hline \multirow[t]{2}{*}{ Współpraca $\mathrm{z}$} & \multicolumn{2}{|c|}{$\begin{array}{l}\text { Posiadanie } \\
\text { karty BUL }\end{array}$} & \multicolumn{2}{|c|}{$\begin{array}{c}\text { Zainteresowanie } \\
\text { wydarzeniami } \\
\text { w BUL }\end{array}$} & \multicolumn{3}{|c|}{$\begin{array}{c}\text { Uczestniczenie w wydarze- } \\
\text { niach rozwijających } \\
\text { zainteresowania }\end{array}$} & \multirow[t]{2}{*}{ Razem } \\
\hline & tak & nie & tak & nie & $\overline{\text { rzadko }}$ & $\begin{array}{l}\text { od czasu } \\
\text { do czasu }\end{array}$ & często & \\
\hline $\begin{array}{l}\text { Z Uniwersytetem } \\
\text { Trzeciego Wieku }\end{array}$ & $\begin{array}{l}10 \% \\
17\end{array}$ & $\begin{array}{l}26 \% \\
42\end{array}$ & $\begin{array}{l}27 \% \\
44\end{array}$ & $\begin{array}{l}9 \% \\
15\end{array}$ & $\begin{array}{l}4 \% \\
6\end{array}$ & $\begin{array}{l}18 \% \\
30\end{array}$ & $\begin{array}{l}14 \% \\
23\end{array}$ & $\begin{array}{l}36 \% \\
59\end{array}$ \\
\hline $\begin{array}{l}\text { Z klubem } \\
\text { emerytów }\end{array}$ & $\begin{array}{l}2 \% \\
3\end{array}$ & $\begin{array}{l}15 \% \\
25\end{array}$ & $\begin{array}{l}14 \% \\
23\end{array}$ & $\begin{array}{l}3 \% \\
5\end{array}$ & $\begin{array}{l}1 \% \\
2\end{array}$ & $\begin{array}{l}6 \% \\
10\end{array}$ & $\begin{array}{l}10 \% \\
16\end{array}$ & $\begin{array}{l}17 \% \\
28\end{array}$ \\
\hline $\begin{array}{l}\mathrm{Z} \text { innymi instytu- } \\
\text { cjami dzialający- } \\
\text { mi na rzecz } \\
\text { seniorów }\end{array}$ & $\begin{array}{l}5 \% \\
8\end{array}$ & $\begin{array}{l}9 \% \\
15\end{array}$ & $\begin{array}{l}11 \% \\
18\end{array}$ & $\begin{array}{l}3 \% \\
5\end{array}$ & $\begin{array}{l}1 \% \\
2\end{array}$ & $\begin{array}{l}4 \% \\
7\end{array}$ & $\begin{array}{l}9 \% \\
14\end{array}$ & $\begin{array}{l}14 \% \\
23\end{array}$ \\
\hline Nie współpracuję & $\begin{array}{l}7 \% \\
11\end{array}$ & $\begin{array}{l}26 \% \\
42\end{array}$ & $\begin{array}{l}17 \% \\
27\end{array}$ & $\begin{array}{l}16 \% \\
26\end{array}$ & $\begin{array}{l}7 \% \\
11\end{array}$ & $\begin{array}{l}12 \% \\
19\end{array}$ & $\begin{array}{l}14 \% \\
23\end{array}$ & $\begin{array}{l}33 \% \\
53\end{array}$ \\
\hline Razem & $\begin{array}{l}24 \% \\
39\end{array}$ & $\begin{array}{l}76 \% \\
124\end{array}$ & $\begin{array}{l}69 \% \\
112\end{array}$ & $\begin{array}{l}31 \% \\
51\end{array}$ & $\begin{array}{l}13 \% \\
21\end{array}$ & $\begin{array}{l}40 \% \\
66\end{array}$ & $\begin{array}{l}47 \% \\
76\end{array}$ & $\begin{array}{l}100 \% \\
163\end{array}$ \\
\hline
\end{tabular}

Źródło: opracowanie własne na podstawie wyników ankiety. 


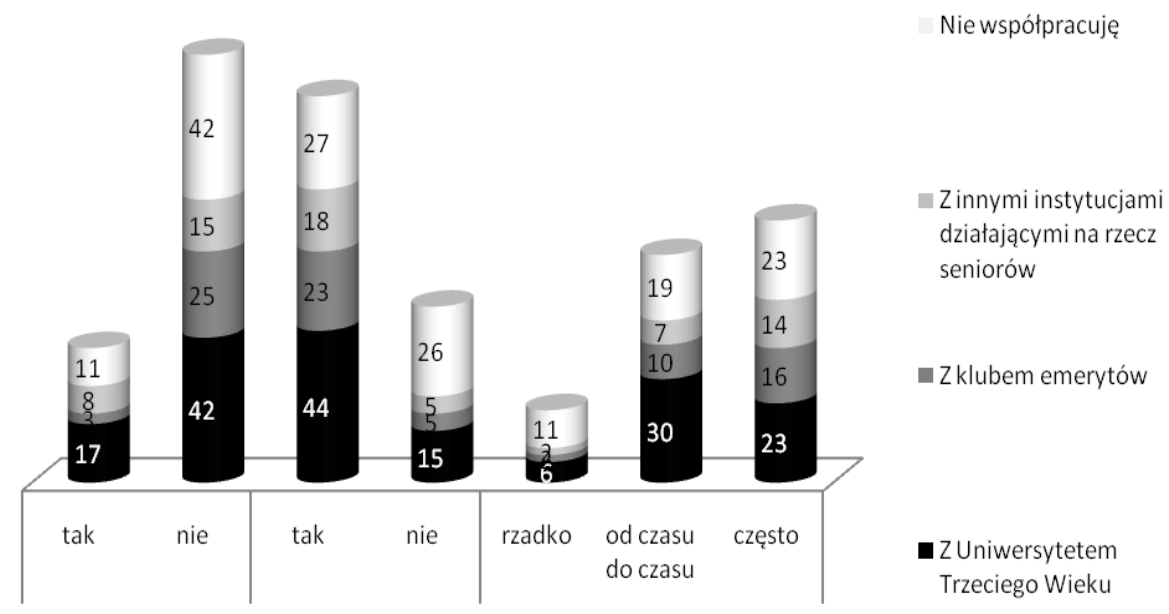

Rys. 3. Aktywność kulturalno-oświatowa, zainteresowanie wydarzeniami w BUŁ i posiadanie karty bibliotecznej uczestników badania, a ich współpraca $z$ instytucjami działającymi na rzecz seniorów Źródło: opracowanie własne na podstawie wyników ankiety.

W tab. 4 i na rys. 3 przedstawiono dane dotyczące aktywności kulturalnoedukacyjnej uczestników badania. Informacje dotyczące współpracy z instytucjami, działającymi na rzecz seniorów, zestawiono z: posiadaniem karty czytelnika BUŁ, zainteresowaniem wydarzeniami w Bibliotece oraz udziałem w wydarzeniach rozwijających zamiłowania.

W badaniu uczestniczyło 59 osób współpracujących z Uniwersytetem Trzeciego Wieku. Zaledwie 17 spośród nich było czytelnikami BUŁ, ale 44 osoby były zainteresowane wydarzeniami kulturalnymi organizowanymi w Bibliotece. 23 ankietowanych zadeklarowało, że często, a 30, że od czasu do czasu - uczestniczyło w wydarzeniach rozwijających zamiłowania.

Drugą, co do liczebności, grupę (53 osoby) stanowili respondenci, którzy nie współpracowali z żadnymi instytucjami, działającymi na rzecz seniorów. Jedynie 11 spośród nich posiadało kartę czytelnika BUŁ, ale 27 ankietowanych było zainteresowanych wydarzeniami w BUŁ. 23 badanych wykazało, że często uczestniczyło w wydarzeniach rozwijających zainteresowania, a 19 - od czasu do czasu.

Z klubami emerytów współpracowało 28 uczestników badania. Zaledwie troje z nich było czytelnikami BUŁ, ale 23 respondentów było zainteresowanych tym, co się dzieje w Bibliotece, a 16 często uczestniczyło w życiu kulturalno-edukacyjnym Łodzi. Z innymi instytucjami, działającymi na rzecz seniorów, współpracowało 23 badanych, spośród nich ośmiu było czytelnikami BUŁ. 
Ogółem osoby starsze współpracujące z różnymi instytucjami, działającymi na rzecz seniorów, stanowiły $67 \%$ wszystkich respondentów (110 osób). $\mathrm{Z}$ powyższych informacji wynika, że uczestnicy badania byli jednymi z najbardziej aktywnych reprezentantów swojego pokolenia.

W dalszej części badania przeanalizowano odpowiedzi starszych czytelników BUŁ odnośnie zakresu wykorzystania zasobów bibliotecznych oraz oczekiwań wobec biblioteki. W tab. 5 i na rys. 4 przedstawiono dane dotyczące sposobu korzystania ze zbiorów BUŁ, zestawiając je z wiekiem respondentów.

Tabela 5

Sposób korzystania ze zbiorów BUŁ a wiek uczestników badania

\begin{tabular}{|l|c|c|c|c|}
\hline \multirow{2}{*}{ Wiek } & \multicolumn{2}{|c|}{ Sposób korzystania ze zbiorów BUL } & \multirow{2}{*}{ Razem } \\
\cline { 2 - 4 } & $\begin{array}{c}\text { Na miejscu - } \\
\text { w czytelniach } \\
\text { i Wolnym Dostępie }\end{array}$ & $\begin{array}{c}\text { Wypożyczanie do } \\
\text { domu }\end{array}$ & $\begin{array}{c}\text { Ze źródel elektronicznych } \\
\text { na stronie } \\
\text { internetowej BUL }\end{array}$ & \\
\hline Poniżej 60. lat & $3 \%$ & $5 \%$ & - & $8 \%$ \\
\hline 60-70 lat & 1 & 2 & $8 \%$ & 3 \\
\hline Powyżej 70. lat & $36 \%$ & $36 \%$ & 3 & 28 \\
& 14 & 14 & $3 \%$ & $21 \%$ \\
\hline Razem & $3 \%$ & $13 \%$ & 1 & $8 \%$ \\
& $46 \%$ & $54 \%$ & 4 & $100 \%$ \\
\hline
\end{tabular}

Źródło: opracowanie własne na podstawie wyników ankiety.

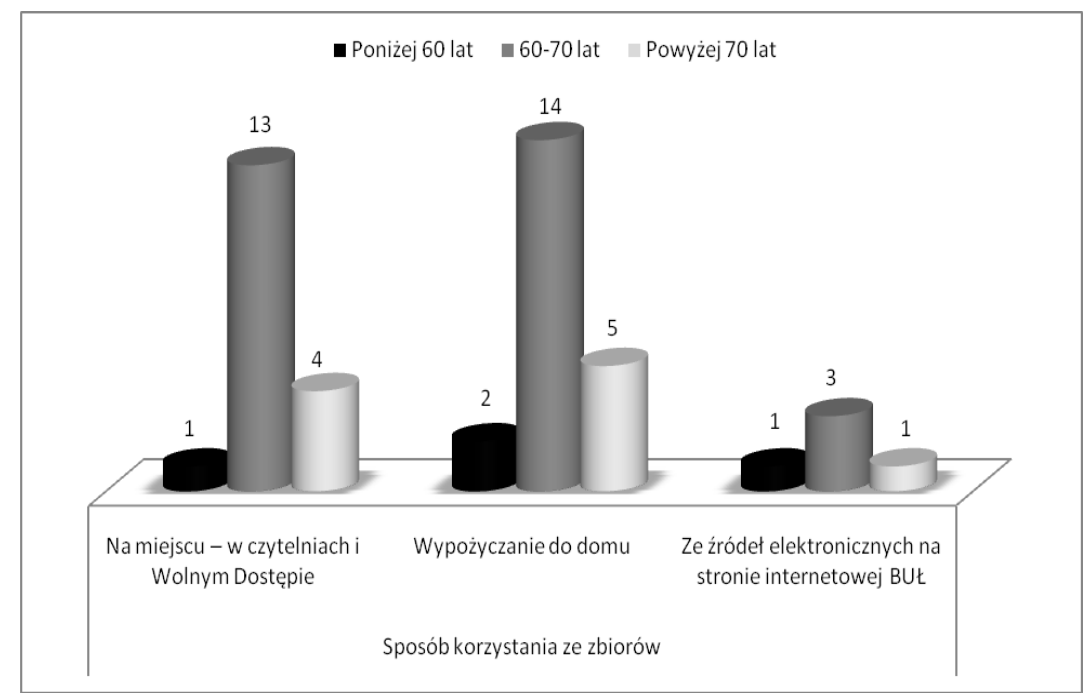

Rys. 4. Sposób korzystania ze zbiorów BUŁ a wiek uczestników badania Źródło: opracowanie własne na podstawie wyników ankiety. 
Tabela 6

Zbiory, z jakich korzystają seniorzy posiadający kartę czytelnika BUŁ

\begin{tabular}{|l|c|c|c|c|}
\hline $\begin{array}{c}\text { Z jakich zbiorów korzysta- } \\
\text { ją czytelnicy BUL }\end{array}$ & $\begin{array}{c}\text { Nie są zainte- } \\
\text { resowani }\end{array}$ & $\begin{array}{c}\text { Korzystają od } \\
\text { czasu do czasu }\end{array}$ & $\begin{array}{c}\text { Korzystają } \\
\text { bardzo często }\end{array}$ & Razem \\
\hline Aktualna prasa & $15 \%$ & $31 \%$ & $54 \%$ & $100 \%$ \\
& 6 & 12 & 21 & 39 \\
\hline Aktualne tygodniki & $59 \%$ & $36 \%$ & $8 \%$ & $100 \%$ \\
lub/i miesięczniki & 23 & 14 & 3 & 39 \\
\hline Czasopisma naukowe & $56 \%$ & $38 \%$ & $5 \%$ & $100 \%$ \\
& 22 & 15 & 2 & 39 \\
\hline Czasopisma popularnonau- & $64 \%$ & $31 \%$ & $5 \%$ & $100 \%$ \\
kowe & 25 & 12 & 2 & 39 \\
\hline Książki naukowe & $46 \%$ & $41 \%$ & $13 \%$ & $100 \%$ \\
& 18 & 16 & 5 & 39 \\
\hline Książki popularnonaukowe & $49 \%$ & $38 \%$ & $13 \%$ & $100 \%$ \\
& 19 & 15 & 5 & 39 \\
\hline Literatura piękna & $26 \%$ & $51 \%$ & $23 \%$ & $100 \%$ \\
& 10 & 20 & 9 & 39 \\
\hline Zbiory specjalne & $74 \%$ & $13 \%$ & $13 \%$ & $100 \%$ \\
& 29 & 5 & $0 \%$ & 39 \\
\hline $\begin{array}{l}\text { Inne (turystyka, przewodni- } \\
\text { ki) }\end{array}$ & $0 \%$ & 1 & & $3 \%$ \\
\hline $\begin{array}{l}\text { Inne (biografie, } \text { ksieggozbiór } \\
\text { OIN) }\end{array}$ & $0 \%$ & $3 \%$ & $0 \%$ & $3 \%$ \\
\hline
\end{tabular}

Źródło: opracowanie własne na podstawie wyników ankiety.

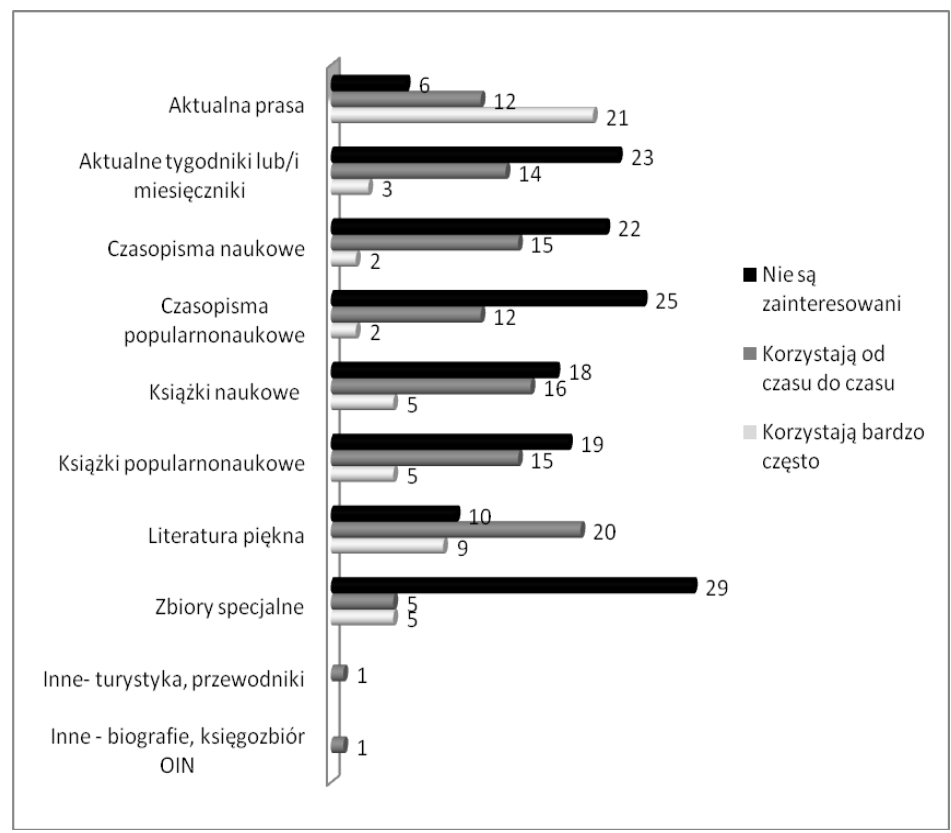

Rys. 5. Zbiory, z jakich korzystają seniorzy posiadający kartę czytelnika BUŁ Źródło: opracowanie własne na podstawie wyników ankiety. 
Większość badanych, korzystających z usług Biblioteki (21 osób), wypożycza książki do domu. Najbardziej aktywną, pod każdym względem, grupą seniorów są osoby w wieku 60-70 lat. W badaniu uczestniczyło ośmiu czytelników powyżej siedemdziesiątego roku życia i trzech poniżej sześćdziesiątego. Rodzaj wykorzystanych zbiorów bibliotecznych przedstawiono w tab. 6 i na rys. 5 .

W największym stopniu starsi czytelnicy BUŁ zainteresowani byli aktualną prasą (11 osób), aktualnymi tygodnikami lub/i miesięcznikami o treści ogólnej (3 osoby) i ekonomicznej (3 osoby), czasopismami naukowymi o tematyce humanistycznej ( 8 osób) i lekarskiej (3 osoby). . Z książek naukowych w BUŁ korzystało bardzo często tylko 5 seniorów, a 16 - od czasu do czasu, z książek popularnonaukowych korzystało bardzo często 5 osób, a 15 - od czasu do czasu, ze zbiorów specjalnych 5 uczestników badania korzystało często i kolejnych 5 - od czasu do czasu.

Najmniejszym zainteresowaniem wśród starszych czytelników BUŁ, uczestniczących w badaniu, cieszyły się zbiory specjalne (29 osób zadeklarowało brak zainteresowania). W dalszej kolejności znalazły się czasopisma popularnonaukowe i naukowe (odpowiednio: 25 i 22 nie zainteresowane osoby). W tab. 7 i na rys. 6 przedstawiono dziedziny interesujące starszych czytelników BUŁ.

Tabela 7

Dziedziny interesujące czytelników BUŁ

\begin{tabular}{|c|c|c|c|c|c|c|}
\hline $\begin{array}{l}\mathrm{Z} \text { jakich zbiorów } \\
\text { korzystają czytel- } \\
\text { nicy BUŁ }\end{array}$ & Ogólne & $\begin{array}{c}\text { Humani- } \\
\text { styczne }\end{array}$ & Prawnicze & $\begin{array}{l}\text { Ekono- } \\
\text { miczne }\end{array}$ & $\begin{array}{l}\text { Nauki ścisle } \\
\text { /Techniczne }\end{array}$ & $\begin{array}{c}\text { Nauki } \\
\text { lekarskie }\end{array}$ \\
\hline Aktualna prasa & $\begin{array}{l}28 \% \\
11\end{array}$ & $0 \%$ & $0 \%$ & $0 \%$ & $0 \%$ & $\begin{array}{l}3 \% \\
1\end{array}$ \\
\hline $\begin{array}{l}\text { Aktualne tygodni- } \\
\text { ki lub/i miesięczni- } \\
\text { ki }\end{array}$ & $\begin{array}{l}8 \% \\
3\end{array}$ & $\begin{array}{l}5 \% \\
2\end{array}$ & $\begin{array}{l}3 \% \\
1\end{array}$ & $\begin{array}{l}8 \% \\
3\end{array}$ & $\begin{array}{l}3 \% \\
1\end{array}$ & $\begin{array}{l}5 \% \\
2\end{array}$ \\
\hline $\begin{array}{l}\text { Czasopisma nau- } \\
\text { kowe }\end{array}$ & $0 \%$ & $\begin{array}{c}21 \% \\
8\end{array}$ & $\begin{array}{l}3 \% \\
1\end{array}$ & $0 \%$ & $\begin{array}{l}3 \% \\
1\end{array}$ & $\begin{array}{l}8 \% \\
3 \\
\end{array}$ \\
\hline $\begin{array}{l}\text { Czasopisma popu- } \\
\text { larnonaukowe }\end{array}$ & $\begin{array}{c}10 \% \\
4\end{array}$ & $\begin{array}{l}13 \% \\
5\end{array}$ & $0 \%$ & $0 \%$ & $\begin{array}{l}8 \% \\
3 \\
\end{array}$ & $\begin{array}{l}5 \% \\
2 \\
\end{array}$ \\
\hline Książki naukowe & $\begin{array}{c}10 \% \\
4\end{array}$ & $\begin{array}{l}28 \% \\
11\end{array}$ & $0 \%$ & $0 \%$ & $0 \%$ & $\begin{array}{c}10 \% \\
4\end{array}$ \\
\hline $\begin{array}{l}\text { Książki popular- } \\
\text { nonaukowe }\end{array}$ & $\begin{array}{l}8 \% \\
3\end{array}$ & $\begin{array}{c}23 \% \\
9\end{array}$ & $0 \%$ & $0 \%$ & $\begin{array}{l}3 \% \\
1\end{array}$ & $\begin{array}{c}18 \% \\
7\end{array}$ \\
\hline Literatura piękna & $0 \%$ & $\begin{array}{l}26 \% \\
10\end{array}$ & $0 \%$ & $0 \%$ & $0 \%$ & $0 \%$ \\
\hline Zbiory specjalne & $0 \%$ & $\begin{array}{l}18 \% \\
7\end{array}$ & $0 \%$ & $0 \%$ & $0 \%$ & $0 \%$ \\
\hline $\begin{array}{l}\text { Inne (historia Ko- } \\
\text { ściola i Żydów } \\
\text { polskich) }\end{array}$ & $0 \%$ & $\begin{array}{l}3 \% \\
1\end{array}$ & $0 \%$ & $0 \%$ & $0 \%$ & $0 \%$ \\
\hline $\begin{array}{l}\text { Inne (bibliografie, } \\
\text { bibliologia) }\end{array}$ & $0 \%$ & $\begin{array}{l}3 \% \\
1\end{array}$ & $0 \%$ & $0 \%$ & $0 \%$ & $0 \%$ \\
\hline
\end{tabular}

Źródło: opracowanie własne na podstawie wyników ankiety. 


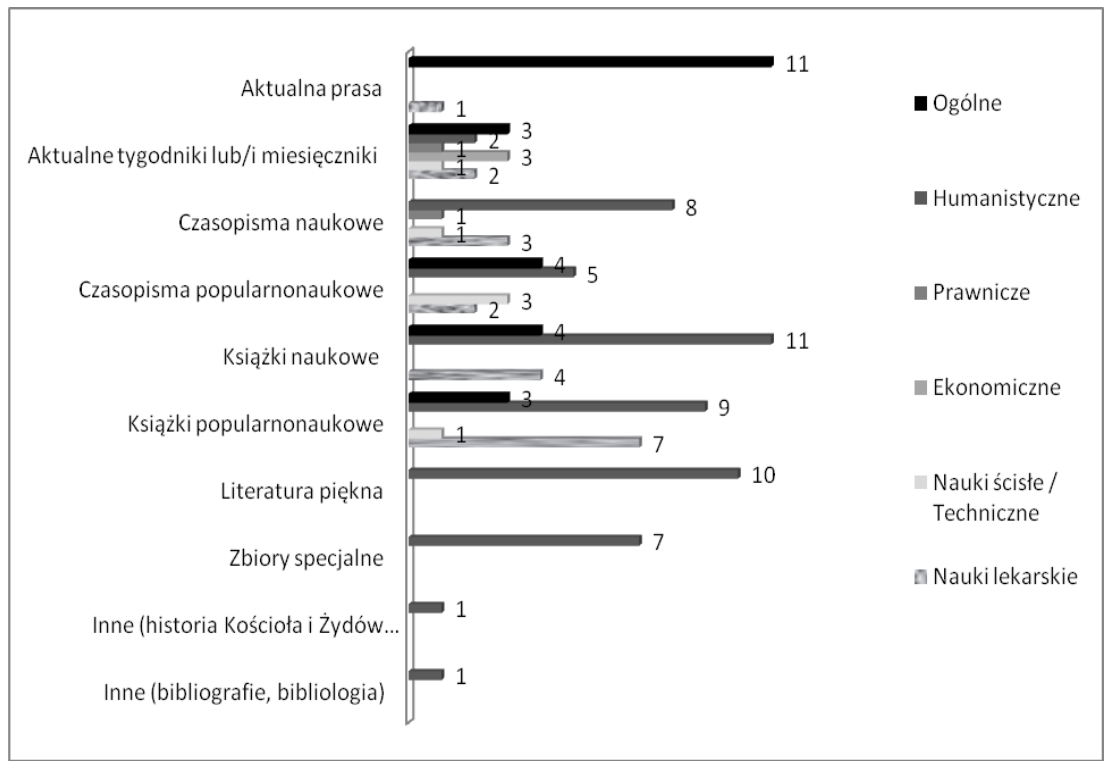

Rys. 6. Dziedziny interesujące czytelników BUŁ

Źródło: opracowanie własne na podstawie wyników ankiety.

W największym stopniu starsi czytelnicy BUŁ zainteresowani byli aktualną prasą (11 osób), aktualnymi tygodnikami lub miesięcznikami o treści ogólnej (3 osoby) i ekonomicznej ( 3 osoby), czasopismami naukowymi o tematyce humanistycznej ( 8 osób) i lekarskiej (3 osoby). Seniorzy interesowali się również humanistycznymi (11 osób) i lekarskimi (4 osoby) książkami naukowymi oraz popularnonaukowymi (odpowiednio: humanistyczne - 9 osób i lekarskie 7 osób). Literaturą piękną zainteresowanych było 10 osób, a zbiorami specjalnymi - 7 humanistów. Jako inną dziedzinę jedna badana osoba zadeklarowała historię Kościoła i polskich Żydów, a kolejna - bibliografie i bibliologię.

Wszystkich uczestników badania zapytano również o ewentualne motywy odwiedzin w Bibliotece (tab. 8, rys. 7).

Bardzo ważnym powodem wizyt w BUŁ dla większości respondentów byłyby wykłady lub/i spotkania, poświęcone literaturze lub/i poezji (50 osób). Dla 29 osób motyw ten okazał się ważny, a dla pozostałych - bez znaczenia. Oferta zbiorów specjalnych byłaby bardzo ważna dla $23 \%$ ankietowanych, ważna dla $20 \%$, a dla innych - bez znaczenia. Dla 29 osób bardzo ważny był swobodny dostęp do księgozbioru i aktualnej prasy. Dla kolejnych 66 - dostęp ten był ważny, ale dla 66 - bez znaczenia. Indywidualny kontakt z bibliotekarzem za bardzo ważny uznało 29 badanych, a za ważny - 66 . 


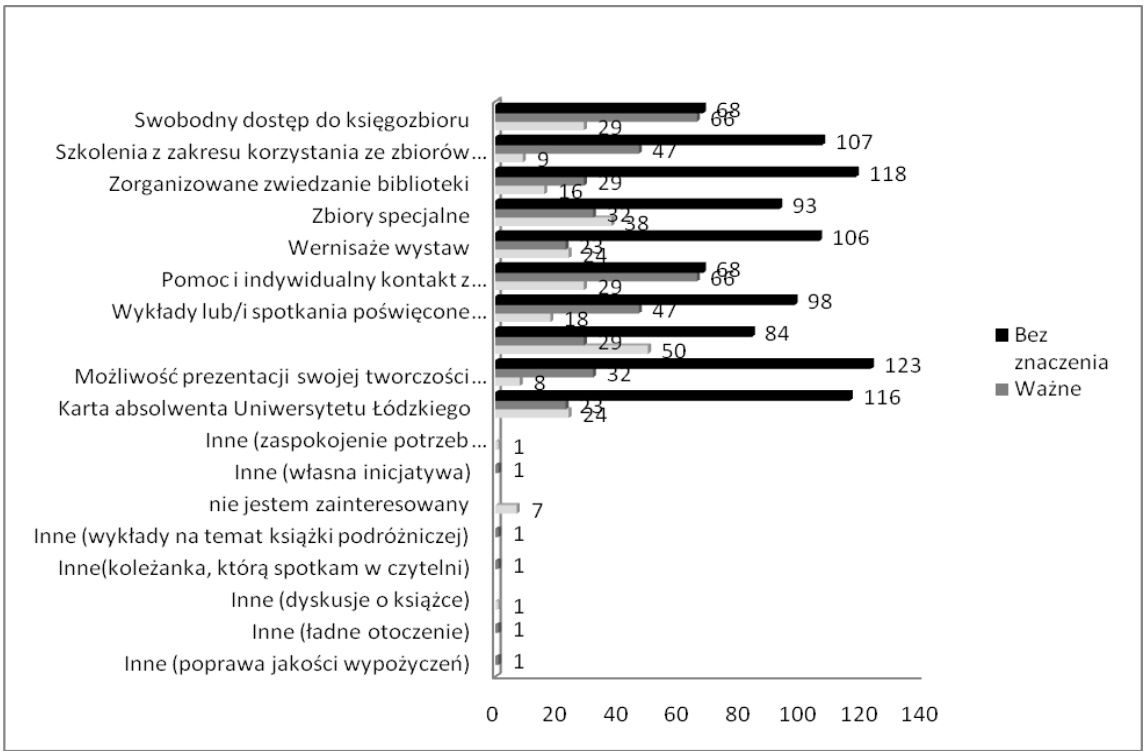

Rys. 7. Motywy odwiedzin Biblioteki Uniwersytetu Łódzkiego

w opinii uczestników badania

Źródło: opracowanie własne na podstawie wyników ankiety.

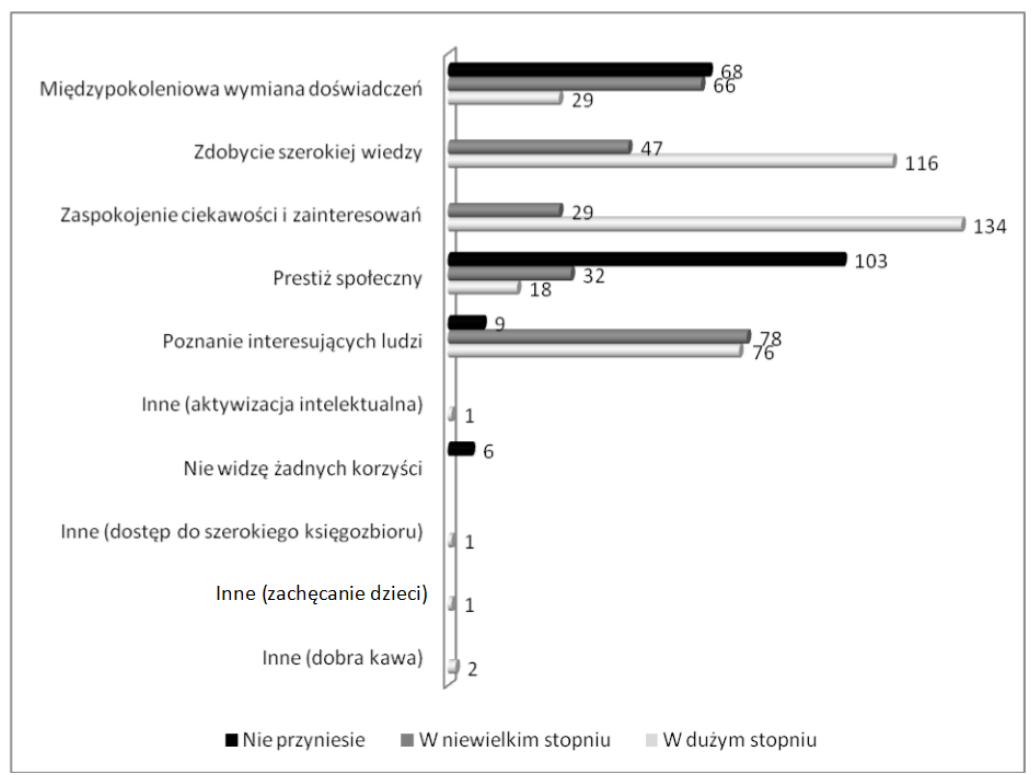

Rys. 8. Opinie respondentów dotyczące korzyści uczestniczenia w wydarzeniach BUŁ

Źródło: opracowanie własne na podstawie wyników ankiety. 
Tabela 8

Motywy odwiedzin Biblioteki Uniwersytetu Łódzkiego w opinii uczestników badania

\begin{tabular}{|c|c|c|c|}
\hline Motywy odwiedzin BUL & Bez znaczenia & Ważne & $\begin{array}{l}\text { Bardzo } \\
\text { ważne }\end{array}$ \\
\hline Swobodny dostęp do księgozbioru i aktualnej prasy & $\begin{array}{l}42 \% \\
68\end{array}$ & $\begin{array}{l}40 \% \\
66\end{array}$ & $\begin{array}{l}18 \% \\
29\end{array}$ \\
\hline Szkolenia z zakresu korzystania ze zbiorów BUL & $\begin{array}{l}66 \% \\
107\end{array}$ & $\begin{array}{l}29 \% \\
47\end{array}$ & $\begin{array}{l}6 \% \\
9\end{array}$ \\
\hline Zorganizowane zwiedzanie Biblioteki UL & $\begin{array}{l}72 \% \\
118\end{array}$ & $\begin{array}{l}18 \% \\
29\end{array}$ & $\begin{array}{l}10 \% \\
16\end{array}$ \\
\hline Zbiory specjalne & $\begin{array}{l}57 \% \\
93\end{array}$ & $\begin{array}{l}20 \% \\
32\end{array}$ & $\begin{array}{l}23 \% \\
38\end{array}$ \\
\hline Wernisaże wystaw & $\begin{array}{l}65 \% \\
106\end{array}$ & $\begin{array}{l}14 \% \\
23\end{array}$ & $\begin{array}{l}15 \% \\
24\end{array}$ \\
\hline Pomoc i indywidualny kontakt $\mathrm{z}$ bibliotekarzem & $\begin{array}{l}42 \% \\
68\end{array}$ & $\begin{array}{l}40 \% \\
66\end{array}$ & $\begin{array}{l}18 \% \\
29\end{array}$ \\
\hline $\begin{array}{l}\text { Wyklady lub/i spotkania poświęcone książce proz- } \\
\text { drowotnej }\end{array}$ & $\begin{array}{l}60 \% \\
98\end{array}$ & $\begin{array}{l}29 \% \\
47\end{array}$ & $\begin{array}{l}11 \% \\
18\end{array}$ \\
\hline $\begin{array}{l}\text { Wykłady lub/i spotkania poświęcone literaturze lub/ } \\
\text { i poezji }\end{array}$ & $\begin{array}{l}52 \% \\
84\end{array}$ & $\begin{array}{l}18 \% \\
29\end{array}$ & $\begin{array}{l}31 \% \\
50\end{array}$ \\
\hline $\begin{array}{l}\text { Możliwość prezentacji swojej twórczości (wiedzy, } \\
\text { doświadczenia) }\end{array}$ & $\begin{array}{l}75 \% \\
123\end{array}$ & $\begin{array}{l}20 \% \\
32\end{array}$ & $\begin{array}{l}5 \% \\
8 \\
\end{array}$ \\
\hline Karta absolwenta Uniwersytetu Lódzkiego & $\begin{array}{l}71 \% \\
116 \\
\end{array}$ & $\begin{array}{l}14 \% \\
23\end{array}$ & $\begin{array}{l}15 \% \\
24\end{array}$ \\
\hline Zaspokojenie potrzeb duchowych, intelektualnych & $0 \%$ & $0 \%$ & $\begin{array}{l}1 \% \\
1\end{array}$ \\
\hline Inne (wlasna inicjatywa) & $0 \%$ & $\begin{array}{l}1 \% \\
1 \\
\end{array}$ & $0 \%$ \\
\hline nie jestem zainteresowany & $0 \%$ & $0 \%$ & $\begin{array}{l}4 \% \\
7\end{array}$ \\
\hline Inne (wyktady na temat książki podróżniczej) & $0 \%$ & $\begin{array}{l}1 \% \\
1\end{array}$ & $0 \%$ \\
\hline Inne (koleżanka, która spotkam w czytelni) & $0 \%$ & $\begin{array}{l}1 \% \\
1\end{array}$ & $0 \%$ \\
\hline Inne (dyskusje o książce) & $0 \%$ & $0 \%$ & $\begin{array}{l}1 \% \\
1\end{array}$ \\
\hline Inne (tadne otoczenie) & $0 \%$ & $\begin{array}{l}1 \% \\
1\end{array}$ & $0 \%$ \\
\hline Inne (poprawa jakości wypożyczania ksią̇ek) & $0 \%$ & $\begin{array}{l}1 \% \\
1\end{array}$ & $0 \%$ \\
\hline
\end{tabular}

Źródło: opracowanie własne na podstawie wyników ankiety.

Motywem bez znaczenia dla przeważającej większości respondentów była możliwość prezentacji własnej twórczości (123 osoby) oraz, co jest nieco zaskakujące, zorganizowane zwiedzanie BUŁ (118 osób). Kartą Absolwenta UŁ nie było zainteresowanych aż 116 ankietowanych.

Respondentów poproszono także o wyrażenie opinii na temat prawdopodobnych i faktycznych korzyści z uczestniczenia w wydarzeniach BUŁ. Zebrane dane przedstawiono $\mathrm{w}$ tab. 9 i na rys. 8 . 
Tabela 9

Opinie respondentów dotyczące korzyści uczestniczenia w wydarzeniach BUŁ

\begin{tabular}{|c|c|c|c|}
\hline $\begin{array}{c}\text { Korzyści uczestniczenia w wydarzeniach } \\
\text { BUL }\end{array}$ & Nie przyniesie & $\begin{array}{l}\text { W niewielkim } \\
\text { stopniu }\end{array}$ & $\begin{array}{l}\text { W dużym } \\
\text { stopniu }\end{array}$ \\
\hline $\begin{array}{l}\text { Międzypokoleniowa wymiana doświad- } \\
\text { czeń }\end{array}$ & $\begin{array}{l}42 \% \\
68\end{array}$ & $\begin{array}{l}40 \% \\
66\end{array}$ & $\begin{array}{l}18 \% \\
29\end{array}$ \\
\hline Zdobycie szerokiej wiedzy & $\begin{array}{l}4 \% \\
6\end{array}$ & $\begin{array}{l}25 \% \\
41\end{array}$ & $\begin{array}{l}71 \% \\
116\end{array}$ \\
\hline Zaspokojenie ciekawości i zainteresowań & $\begin{array}{l}4 \% \\
6\end{array}$ & $\begin{array}{l}14 \% \\
29\end{array}$ & $\begin{array}{l}82 \% \\
134\end{array}$ \\
\hline Prestiż społeczny & $\begin{array}{l}63 \% \\
103\end{array}$ & $\begin{array}{l}20 \% \\
32\end{array}$ & $\begin{array}{l}11 \% \\
18\end{array}$ \\
\hline Poznanie interesujących ludzi & $\begin{array}{l}6 \% \\
9\end{array}$ & $\begin{array}{l}48 \% \\
78 \\
\end{array}$ & $\begin{array}{l}47 \% \\
76\end{array}$ \\
\hline Inne (aktywizacja intelektualna) & $0 \%$ & $0 \%$ & $\begin{array}{l}1 \% \\
1\end{array}$ \\
\hline Nie widzę żadnych korzyści & $\begin{array}{l}4 \% \\
6\end{array}$ & $0 \%$ & $0 \%$ \\
\hline Inne (dostęp do szerokiego księgozbioru) & $0 \%$ & $0 \%$ & $\begin{array}{l}1 \% \\
1\end{array}$ \\
\hline Inne (zachęcanie dzieci) & $0 \%$ & $0 \%$ & $\begin{array}{l}1 \% \\
1 \\
\end{array}$ \\
\hline Inne (dobra kawa) & $0 \%$ & $0 \%$ & $\begin{array}{l}1 \% \\
2\end{array}$ \\
\hline
\end{tabular}

Źródło: opracowanie własne na podstawie wyników ankiety.

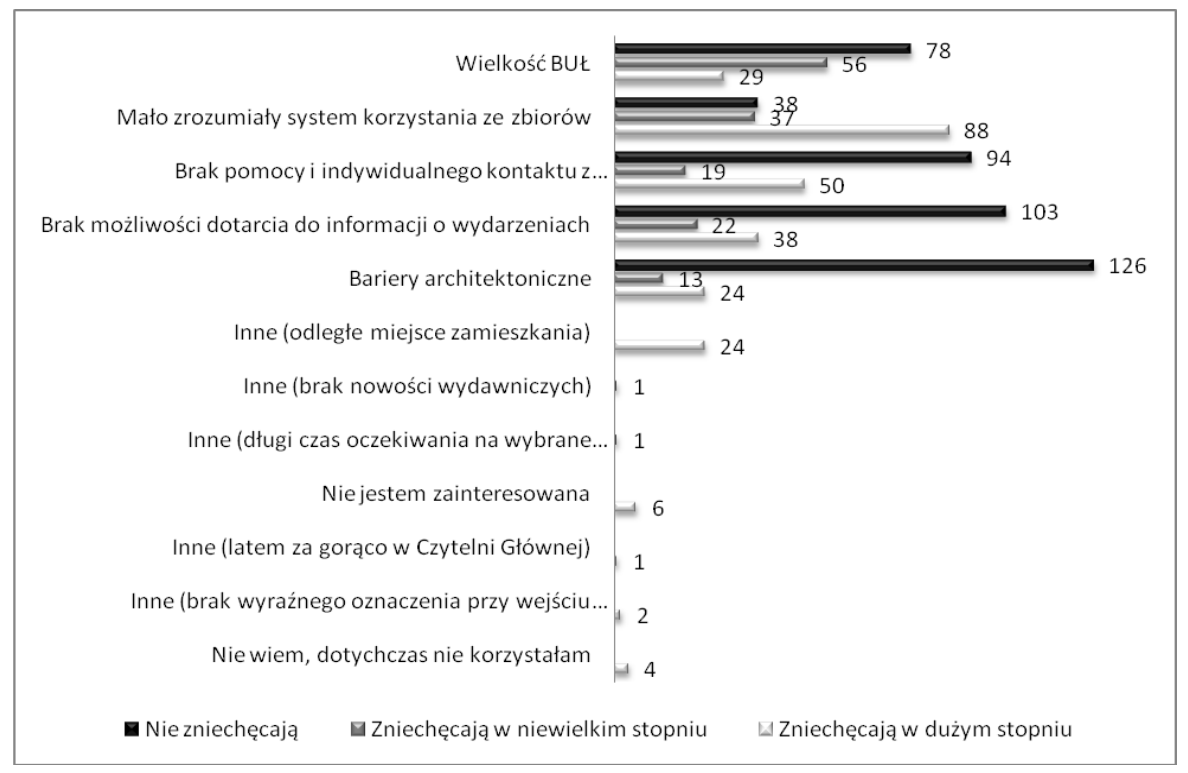

Rys. 9. Opinie respondentów dotyczące czynników zniechęcających do korzystania z usług BUŁ

Źródło: opracowanie własne na podstawie wyników ankiety. 
Tabela 10

Opinie respondentów dotyczące czynników zniechęcających do korzystania z usług BUŁ

\begin{tabular}{|c|c|c|c|}
\hline $\begin{array}{c}\text { Czynniki zniechęcające do korzystania } \\
\text { z usług BUL }\end{array}$ & $\begin{array}{c}\text { Nie } \\
\text { zniechęcają }\end{array}$ & $\begin{array}{c}\text { Zniechęcają } \\
\text { w niewielkim } \\
\text { stopniu }\end{array}$ & $\begin{array}{l}\text { Zniechęcają } \\
\text { w dużym stop- } \\
\text { niu }\end{array}$ \\
\hline Wielkość BUL & $\begin{array}{l}48 \% \\
78\end{array}$ & $\begin{array}{l}34 \% \\
56\end{array}$ & $\begin{array}{l}18 \% \\
29\end{array}$ \\
\hline $\begin{array}{l}\text { Mało zrozumiały system korzystania } \\
\text { ze zbiorów }\end{array}$ & $\begin{array}{l}23 \% \\
38\end{array}$ & $\begin{array}{l}23 \% \\
37\end{array}$ & $\begin{array}{l}54 \% \\
88\end{array}$ \\
\hline $\begin{array}{l}\text { Brak pomocy i indywidualnego kontak- } \\
\text { tu z bibliotekarzem }\end{array}$ & $\begin{array}{l}58 \% \\
94\end{array}$ & $\begin{array}{l}12 \% \\
19\end{array}$ & $\begin{array}{l}31 \% \\
50\end{array}$ \\
\hline $\begin{array}{l}\text { Brak możliwości dotarcia do informacji } \\
\text { o wydarzeniach }\end{array}$ & $\begin{array}{l}63 \% \\
103\end{array}$ & $\begin{array}{l}13 \% \\
22\end{array}$ & $\begin{array}{l}23 \% \\
38\end{array}$ \\
\hline Bariery architektoniczne & $\begin{array}{l}77 \% \\
126 \\
\end{array}$ & $\begin{array}{l}8 \% \\
13 \\
\end{array}$ & $\begin{array}{l}15 \% \\
24 \\
\end{array}$ \\
\hline Inne (odlegle miejsce zamieszkania) & $0 \%$ & $0 \%$ & $\begin{array}{l}15 \% \\
24\end{array}$ \\
\hline Inne (brak nowości wydawniczych) & $0 \%$ & $\begin{array}{l}1 \% \\
1\end{array}$ & $0 \%$ \\
\hline $\begin{array}{l}\text { Inne (dlugi czas oczekiwania na wybrane } \\
\text { pozycje, brak aktualnych ważnych wydaw- } \\
\text { nictw) }\end{array}$ & $0 \%$ & $\begin{array}{l}1 \% \\
1\end{array}$ & $0 \%$ \\
\hline nie jestem zainteresowana & $0 \%$ & $0 \%$ & $\begin{array}{l}4 \% \\
6\end{array}$ \\
\hline $\begin{array}{l}\text { Inne (latem za goraco w Czytelni Glów- } \\
\text { nej) }\end{array}$ & $0 \%$ & $0 \%$ & $\begin{array}{l}1 \% \\
1 \\
\end{array}$ \\
\hline $\begin{array}{l}\text { Inne (brak wyraźnego oznaczenia przy } \\
\text { wejściu lokalizacji ksiązek } w \text { Wolnym } \\
\text { Dostepie) }\end{array}$ & $0 \%$ & $0 \%$ & $\begin{array}{l}1 \% \\
2\end{array}$ \\
\hline nie wiem, dotychczas nie korzystatam & $0 \%$ & $0 \%$ & $\begin{array}{l}2 \% \\
4\end{array}$ \\
\hline
\end{tabular}

Źródło: opracowanie własne na podstawie wyników ankiety.

Największą korzyść z korzystania z Biblioteki ankietowani seniorzy widzieli w możliwości zaspokojenia ciekawości i zainteresowań (134 badanych). Drugą istotną wartością było zdobycie szerokiej wiedzy (116 badanych). Na trzecim miejscu znalazła się możliwość poznania interesujących ludzi (76 badanych). Zaledwie 6 badanych nie dostrzegło żadnych korzyści z tytułu udziału w wydarzeniach BUŁ.

$\mathrm{Na}$ koniec ankietowanych zapytano o to, co ich zniechęca do wizyt w Bibliotece (tab. 10, rys. 9).

Większość respondentów (88 osób) uznała, że czynnikiem najbardziej zniechęcającym do odwiedzin Biblioteki jest mało zrozumiały system korzystania ze zbiorów. Kolejnych 37 ankietowanych zaznaczyło odpowiedź, że system ten zniechęca ich w niewielkim stopniu. Brak możliwości dotarcia do informacji o wydarzeniach organizowanych w BUŁ zniechęca w dużym stopniu aż 38 badanych, a $22-\mathrm{w}$ niewielkim stopniu. 


\section{Podsumowanie}

Seniorzy stanowią grupę czytelników dysponujących ilością czasu wolnego, który mogą spędzić w bibliotece, przeznaczając go na korzystanie z tradycyjnej, drukowanej formy książek, a także uczestnicząc w wydarzeniach kulturalnych organizowanych na terenie biblioteki uniwersyteckiej. Przeprowadzone badania wykazują, że rola BUŁ w życiu lokalnej społeczności osób starszych jest niewielka. Seniorzy nie wykorzystują w pełni możliwości, jakie oferuje Biblioteka. Nie korzystają ze specjalistycznego sprzętu i bogatego księgozbioru BUŁ oraz nie uczestniczą w wernisażach wystaw, spotkaniach $\mathrm{z}$ autorami, prelekcjach i innych. W BUŁ z roku na rok jest coraz mniej czytelników regularnie korzystających ze zbiorów o czym świadczą statystki, a także bieżąca obserwacja ruchu czytelniczego. Potrzebna jest bardziej aktywna promocja zasobów bibliotecznych oraz wydarzeń kulturalnych, odbywających się w placówce. Biblioteka powinna skierować ofertę również do najbardziej aktywnych seniorów, będących na przykład słuchaczami Uniwersytetu Trzeciego Wieku, spośród których niewielki procent korzysta ze zbiorów BUŁ. Trzeba jednak podkreślić, że zarejestrowani starsi użytkownicy Biblioteki są zadowoleni z oferowanych usług bibliotecznych i uniwersalnych zbiorów.

Badania wykazały, że barierą dla osób starszych jest mało przejrzysty system korzystania ze zbiorów oraz sposób oznakowania miejsc i pomieszczeń bibliotecznych. Istnieje potrzeba ustawienia przy wejściu planszy z wyraźnym oznaczeniem lokalizacji książek w Wolnym Dostępie. Również korzystanie z katalogów elektronicznych może stanowić barierę, dlatego konieczne jest przeznaczenie jednego, odpowiednio wyposażonego w instrukcję stanowiska komputerowego.

Korzystanie ze zbiorów bywa też utrudnione ze względu na bariery komunikacyjne, to znaczy brak umiejętności wyrażenia swoich oczekiwań na skutek małego zasobu wiedzy czy też pewnej nieporadności. Problemy komunikacyjne wynikają niekiedy z winy pracowników Biblioteki, którzy nie potrafią lub nie chca pomóc starszej osobie $\mathrm{w}$ realizacji oczekiwań. Poza podstawowymi formami grzecznościowymi zachęcającymi do zadania pytania i poproszenia o wsparcie, ważne jest nawiązanie prostej, otwartej i nieskomplikowanej interakcji z czytelnikiem, a także fachowa pomoc $\mathrm{w}$ korzystaniu $\mathrm{z}$ katalogów i księgozbioru. Wielu respondentów odpowiadało, że korzysta z dzielnicowej biblioteki publicznej, ponieważ przyzwyczaili się do kameralnej placówki i zaprzyjaźnionej pani bibliotekarki. W dużej bibliotece uczelnianej czują się anonimowi i nieco zagubieni. Seniorzy wymagają indywidualnego kontaktu z bibliotekarzem. Jest on ważny dla $40 \%$ respondentów, a dla $18 \%$ badanych bardzo ważny.

Zainteresowanie czytelnika 55+ Biblioteką UŁ wymaga ze strony personelu bibliotecznego większej troski i uwagi, a także cierpliwości. Uważamy, że warto podjąć pewien wysiłek, aby w wyniku okazanego na początku wsparcia 
i pomocy zyskać nowych czytelników, systematycznie korzystających ze zbiorów bibliotecznych.

Starzenie się społeczeństwa i zwiększenie liczby osób starszych jest cechą naszych czasów. Część seniorów jest aktywna, łamie stereotypy, chce doskonalić swoje umiejętności i poszerzać wiedzę. Świadczy o tym między innymi wzrost liczby uczestników zajęć Uniwersytetów Trzeciego Wieku, działających w Łodzi pod patronatem Uniwersytetu Łódzkiego, Politechniki Łódzkiej, Wyższej Szkoły Informatyki i Umiejętności, Akademii Humanistyczno-Ekonomicznej, Wyższej Szkoły Ekonomii i Zarządzania. W Łodzi istnieje też Salezjański Uniwersytet Trzeciego Wieku oraz Uniwersytet Trzeciego Wieku prowadzony przez Fundację Gimnazjum i Liceum Ogólnokształcącego im. Jana Pawła II. Skoro w aktywizację seniorów włączają się uniwersytety i wyższe uczelnie, to i biblioteki uczelniane powinny dostosować swoją ofertę do czytelnika 55+.

Biblioteka, jako nowoczesna organizacja społeczeństwa wiedzy, powinna wykazywać zdolność dostosowywania się do zmian społecznych, demograficznych i kulturalnych, zachodzących w kraju, a nawet ich wyprzedzania i aktywnego kształtowania nie tylko środowiska uczelnianego, ale też lokalnego. Rolą każdej biblioteki, a przede wszystkim akademickiej jest dostarczenie usług i produktów w postaci informacji oraz wiedzy, które zapewnią ludziom młodszym i starszym możliwość doskonalenia się oraz funkcjonowania w ustawicznie zmieniającym się otoczeniu. Biblioteka akademicka nastawiona na całe społeczeństwo będzie zawsze tętniła życiem, a trud bibliotekarzy włożony w upowszechnianie wiedzy i kultury zostanie doceniony.

\section{Bibliografia}

Aleksandrowicz R., Biblioteka w życiu ludzi starszych, [w:] red. M. Komza, Oblicza kultury ksiązki. Prace i studia z bibliologii i informacji naukowej, Wrocław 2005, s. 151-167.

Aleksandrowicz R., Czy jesteśmy społeczeństwem otwartym na seniorów. O możliwości dostępu osób starszych do informacji i biblioteki, [w:] red. J. Dzieniakowska, Książka, biblioteka, informacja. Między podziałami a wspólnota, Kielce 2007, s. 473-483.

Fabiś A., Edukacja seniorów - odpowiedź na wymagania współczesności, [w:] red. A. Fabiś, Wyzwania wspótczesnej edukacji dorostych. Unowocześnianie procesu kształcenia dorostych. T. 2, Mysłowice-Zakopane 2005, s. 153-163.

Hrapkiewicz H., Uczestnictwo w Uniwersytecie Trzeciego Wieku jako sens życia człowieka, [w:] red. J. Rzepka, Problematyka osób w wieku starszym. Materiaty z III Ogólnopolskiego Seminarium Naukowego, Mysłowice, 22 maja 2004 roku, Mysłowice-Zakopane 2006, s. 49-61.

Konieczna-Woźniak R., Uniwersytety Trzeciego Wieku w Polsce. Profilaktyczne aspekty edukacji seniorów, Poznań 2001.

Leszczyńska-Rejchert A., Człowiek starszy i jego wspomaganie - w stronę pedagogiki starości, Olsztyn 2005.

Leszczyńska-Rejchert A., Stereotypy starości w perspektywie społeczno-pedagogicznej, [w:] red. A. Leszczyńska-Rejchert, Stereotypy a starość i niepelnosprawność: perspektywa społeczno-pedagogiczna, Kraków 2012, s. 17-27. 
Restak R.M., Starsi znaczy mądrzejsi: jak zachować przez całe życie doskonata sprawność umystu, Warszawa 1999.

Szarota Z., Gerontologia społeczna i oświatowa. Zarys problematyki, Kraków 2004.

Ziębińska B., Uniwersytety Trzeciego Wieku jako instytucje przeciwdziałające marginalizacji osób starszych, Katowice 2010. 